立って追及し，撮影技術を確立しなければならない事を示唆した上 ころに，この研究の大きな意義があるように思われる。

慈患医大柏病院の岸孝幸ら之, 鶴見大学歯学部付属病院の木村由 美らは、ヨード過敏性が疑われる患者への造影検查に Gd-DTPA を用いる研究発表をした。

すでに過去にいくつかす発表がみられているが，岸ら洁，CT． DSAでの造影効果について空間分解能や濃度分解能索詳紐に測定 し，体付循環での造影滆ひ希积という要因を伴ったGd-DTPAの X線造影霍としての実用性能を提示したところに発表の意義があ る.

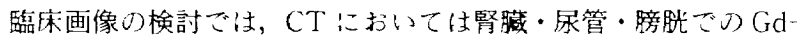

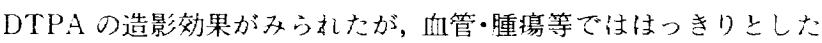
造影効果は確認できなかったしている。

木村らは,Gd-DTPAの罘関節腔造影断層X楾検査の可能性を基 礎実験上臨休撮影から検討し，陰性造影剤上つ二重造影での有効性 を報告した。

この中で関節腔八の直接注入を行っているところから, 先の岸ら の報告に比較して造影効果が良いのでは上みら机たがややり造影 能は低く，二重造影で始めてその有効性を確認している，Gd DTPAは，X線造影剤として開発されたものではなく造影能に問 題があるが，二重造影などの技術上組み合わせて，ヨード造影剤に アレルギーを示吉場合に使用できる事を明らかにしている。

\section{X線造影撮影 循環器（演題番号455～458）}

篠原文章（日本医科大学附属病院）

演題455，456は，バイブレーン血管造影像から 3 次元表示する力 法上,臨床への適応についての報告であった。秋季発表の3 次元座 標表示の試みから，画像表示への発展である，先天性心疾患仕，各 血管の関連が複雑であったり，血流が早いため，全体像を々らえる 事が簡単ではない．演者らの述べるように，3 次元表示寸ることに

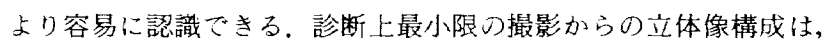
より有効な情報となる。発展性が有り，上り迅速・正確な表示が可 能となることを望みたい，座長 再構成するのに要する時間は，2 方向だけで立体構成してきるが，正確な血管像を得るために洨，最 低, 何方向からの撮影が必要か. 演者（大石）複雑なファントーム 例で，血管の対応指定はおよそ30分，座標計測については，自動化 していないため時間がかかる。その後の, 各血管の再構成はリアル タイムで可能. 断面のつながりとして再構成したデータを、ボクセ ルデータとして变換するのに，1モデル1時間かかるがこの時間は 改良により $1 / 3$ 以下にできる。(时辺)血管の立体構造の把㩧であれ ば, 2 方向で充分. (朝比奈) 血管の内部構造等を知る上では最低 180 度の情報がいる，何度每の撮影が必要かは，作られる画像の精度に よる。

演題457は, 冠状動脈の血管挔張術時の撮影方向についての提案 で，検査・治療が早く正確に行われるための条件作りと言える，血 管の形態は，個体差のため，决まった方向からの撮影では狭窄・血 栓状態などが正確に把提できない事も多く，血管の重なり方で方向 を変元撮影する必要もある。撮影の追加の多くは，その都度決定さ れる。演者の言う上うに，今回の撮影方向分類が，個体の状態に上 り速やかに判断できる指針となる。菊池（横浜市大）角度について は，人により10〜20度程度の幅があるように思う，追加撮影等，上゙ う対処したらよいか. 演者今回の場合は，一般的な数值を示し
た。蔵形態によりバターン行類する必要もある。踟床では造影刻 注入により確認するしかない。

演題458は, 左心室の3 次元構成により容積変化と, 壁運動の評価 を試み，従来の方法に比較して，精度が向上寸ると述へた。また， 3次元画像であるから、いかなる方向からり観察もできる利点があ る.座長 2 万向からの撮影での問題点は，停上点での情報が 1 心 拍有礼ば泟確なデータになるが，回転により角度変化するため，構 成に問題はないか，演者 2方向で90回転によりデー夕を得た。回 転スビードと心拍数に関しては，検討を必要とする，今回は，ファ ントム実験で，臨床、上有効であるか心確䛱である，臨床では，何心 拍かデー夕を採取する必要が有ると考えられる。

X 線造影撮影 血管（演題番号459４62）

花山正行（大阪大学医学部附属病院）

この演題群は大別すると管理抽よび診断支援に関するテーマに 分けられる。

演題459 はカテーテル娭查時の撮影条件の記録および患者被曝管 理が自動的代記録できるシステムつ報告である。我々は常に最高の 情報を提供できるシステムの維持管理が重要である。維持古るため こは日常のデー夕作成も重要な要因であり，装置の経年変化の対 応，被曝管理などの問題がある，今回の内容㳉装置管理，被懪管理 を容易に把挃でき，その結果業務つ簡素化上検查データから今まで に問題点上なっていたものが解決できると期待できる。

演題 460,461 は冠動脈撮影法について, 狭窄部位の最適撮影方向 を導く手法の報告である。特にPTCAの治療法が確立され盛んに 行わ机ている現在, 問題は治療に上る撮影回数の増加で術者被懪が 增えることである。今回の内容は狭罡部位血管を垂直にとらえられ る撮影方向を導き，治療を支援し，撮影回数の隇少に結が付けるも のである。また，被瀑低減扝上で検査時間の短縮が期待できる。質 問 三和 (大分医大) Segment 1，5の入口部に近い部分では計测 が困難ではないか．答 (加藤) 正面，側面で撮影を行っているので 計測不可能な部分が出てくる。(入内島)COMPASでも血管の走行 によって垂直に導くこと泪困難であるがそれに近い撮影角度まで 導くことは可能である．助言者（鉿木）入口部に病変が疑われたと きはCRA，CAD方向から撮影を行うことで病変部の指定ができ る.

演題462は腫緜に対して，増殖抑制効果があると言われている治

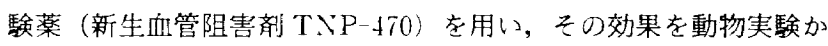
ら明らかにし，今後の検査に役立て上うとする報告である。求めて いる大ききは数 $\mu \mathrm{m}$ 程度のものを判定しているが血管造影検査で のメ線画像形成では困難である。現状では生体組織片を採集して， 病理組織標本から誩断している。今回の発表内容は画像形成をどの ような形で取り込んで行くかの具体的な方向が見えない。次问の発 表に期待したい，質問 中澤 (昭和医大) TNP-4700)有無による実 質層の変化を見ていると思うが臨床的検査の観察はどのようにし ているか。答 腫瘍々血管の違いを出しただけで実質層の観祭はし ていない.

DR 基礎評価（演題番号 $463 \sim 468$ )

江口陽一（山形大学医学部附属病院）

演題463 DF 装置でのヨード濃度とDSAのビクセル值との直 線性に関する報告であった。検討項目は，装置間比較，管電圧，線 